\title{
Sindh's Imbalanced Urbanization: Seeking Sustenance through Revival of Historic Urban Centres
}

\author{
Anila Naeem \\ Department of Architecture and Planning, NED University City Campus \\ Maulana Din Mohammad Wafai Road, Karachi - 74200, Pakistan
}

Tel: 92-300-824-1387 / 92-21-9921-3058

Fax: 92-21-3241-6830 / 92-21-9926-1255

E-mail: anaeem@neduet.edu.pk

Received: June 18, 2011

Accepted: September 1, 2011

doi:10.5539/jsd.v4n5p94

\begin{abstract}
Sindh, Pakistan's second largest province with 30.44 million inhabitants has always been the country's most urbanized region; but its urban population is un-evenly distributed - i.e. $71 \%$ concentrating in only three major cities. This imbalanced urban growth is the result of disproportional distribution of development investments through public or private sector establishments. Additionally the natural resources have been mismanaged drastically creating socio-economic disparity, poverty alleviation and urban-rural divide in the region. Seeds of these problems are accredited to colonial period changes; further worsened by latter $20^{\text {th }}$ century developments transforming the landscape. Lack of participatory community involvement in development processes, insensitive spoliation of natural resources and a disregard for traditional built fabric has resulted in loss of unique historic environments; craving for recognition as invaluable regional resources. This paper seeks to instigate a consciousness towards significance of historic urban centers, identify directions to reinstate their value as historic, economic and environmental assets, and gauge their potentials for a possible revival directed towards restructuring a balanced and sustained urbanization in the region.
\end{abstract}

Keywords: Sindh, Pakistan, Sustainable development, Historic towns

\section{Introduction}

In recent decades there have been increasing concerns worldwide, over rapidly depleting resources of the Earth, making it an urgent requirement of our times to give due regard to our natural and built environments; safeguarding the long-term interests of our planet. Sustainability has thus become a core issue, presently emphasized in development policies across the world. The Brundtland Report defines 'sustainable development' as what 'meets the need of the present without compromising the ability of future generations to meet their own needs' implying that the 'goals of economic and social development must be defined in terms of sustainability in all countries' (WCED, 1987). This report further extends the concept of sustainability to 'reviving economic growth; meeting essential needs for jobs, food, energy, water and sanitation; ensuring a balance between populations and resources; conserving and enhancing the resource base; reorienting technology and managing risk; merging the environment and economics in decision-making; and reorienting international economic relations' (Knox, 2009). These concepts make strong justification for supporting conservation of built heritage for its 'resource value' - over and above architectural or historic values (Rodwell, 2003). In the context of heritage conservation sustainability has been defined by Sir Bernard Feilden as the process of 'prolonging the life of a building in order to contribute to a saving of energy, money and materials'; equating conservation and sustainability as 'synonymous' and 'complimentary' with three simple principles that are common to both: 'wise use of resources to ensure their continuity of supply; minimum intervention to fabric and cultural identity (physical, social, economic, artistic); and constructive evolution as opposed to destructive revolution' (Rodwell, 2003; 60).

The defined aim of sustainable development is to produce cities or urban centers that utilize available natural resources with efficiency and equity; and provide an environment that enhances livability, i.e. providing opportunities of economic benefit, social well-being and healthy environment for its residents (Elkin, 1991; Breheny, 1992; Williams, 2000). Existing building stock of historic towns is conceived as already spent capital, thus a resource - if put to wise use consumes less energy and minimized waste; additionally having benefits of 
better environmental performance ( Wallace, 1999; Heath, 2000; Airs, 2006; Brimblecombe, 2006). Thus traditional environments have immense potentials that support the goals of sustainable development, hence need to be given due regard. This has been well realized in many countries of the European region that now incorporate policies for area-based conservation mechanisms and management programs as a priority, encouraging wider implementation of these concepts through funding mechanisms 'tailored towards sustainable, conservation-led regeneration, taking into consideration social and economic needs' (Pickard, 2002; p85). The following general principles are recommended to achieve sustainable management of historic centers: respect for community; improvement in quality of life; maintaining identity, diversity and vitality; minimizing depletion of non-renewable heritage assets; changing attitudes and perceptions; empowering community action and responsibility through involvement; framing suitable policy to incorporate objectives of conservation and sustainable development; and defining the capacity by which the historic center can permit change (Pickard, 2001; p290). These principles lead towards achieving an enhanced 'livability' - defined as encompassing four essentials; environmental quality, physical attributes (morphology, form, layout, amenities and architecture of town) functional effectiveness, and social behavior/ public safety; additionally the socio-cultural dimension that gives an identity and sense of place (Knox, 2009).

In the light of literature supporting conservation and regeneration of historic towns as a possible means for achieving sustainable development, the region of Sindh has been analyzed and studied in its historic context to evaluate the potentials of its historic built environments as a possible source to seek sustenance that directs towards a more balanced urbanization. The methodology used for this research involves extensive literature review of historical sources on the region geared towards gaining a comprehensive understanding of the patterns of urbanization within the region in its historic timeframe; eventually leading towards identification of the important urban centers that contributed towards establishing the socio-economic dynamics of the region. The research process made use of predefined and well established definitions of towns and urban centers as a starting point (Carter, 1983; Garnier and Chabot, 1967); through which towns of historic significance were shortlisted, and then studied in detail to identify the core factors shaping their traditional built form in order to define their characteristic features and values of significance.

\section{Background to the Sindh}

Sindh the second largest province of Pakistan in terms of population, spreads over an area of $1,40,914 \mathrm{~km}^{2}$ (54407 sq. miles); having a total population of 30.44 million (as of 1998 census records) that makes $23 \%$ of Pakistan's total for that year. Previous census records indicate the province always being the most urbanized region of the country; particularly the post-Independence figures that reflect on rapid urbanization; increasing from $29.24 \%$ in 1951 to $48.9 \%$ in 1998 - much higher than the overall average of $32.5 \%$ for Pakistan; or any other of its provinces (GoP, 2009; IUCN, 2007; IUCN, 2004). In addition to being the most urbanized province, Sindh is also the highest contributor to national revenue, collecting $70 \%$ of Pakistan's income tax and $62 \%$ of its total sales tax. Sindh also houses $70 \%$ of Pakistan's industry ( $60 \%$ being in Karachi alone), and is the source of major natural resources, including among others $60 \%$ of the country's oil fields and $44 \%$ of its gas fields. In spite of these impressive figures the province's share in national revenue transfer till recently has only been $23.28 \%$ (Sorley, 1959) (since 2010, through NFC award this is to be increased to approximately $29 \%$ ).

The administrative boundaries of Sindh are more or less defined by natural features of the landscape; the Kirthar Mountain Ranges create a natural demarcation on western borders adjoining Baluchistan; the Arabian Sea marking southwest limits; the Runn of Kutch on the south; the Indian States of Rajasthan and Gujarat with the great Rajasthan Desert forming a natural barrier on the eastern bounders; and the plains of Punjab on northeast. Generally speaking Sindh is categorized as the 'Lower Indus Basin' but due to its varied physiographic features it is sub-divided into four distinct topographical areas: Kirthar Mountain Range (Kohistan), Desert Belt (Tharparkar), Alluvial Plains and Indus Delta (IUCN, 2007; IUCN, 2004; Sorley, 1959; Thornton, 1844) (fig 1); each having its distinct communities, with particular ethnography, dialect and folklore; that for centuries sustained themselves on natural resource based economies. Excessive exploitation of these resources, combined with uncontrolled urbanization/ development trends of recent decades, not giving enough respite for revival, have disturbed the ecosystems and pushing these indigenous communities on the verge of extinction.

Sindh being an arid zone, depends entirely on Indus River as its perennial source of water - covering 580 miles along the N-S axis of the province; its width varying from $480-1600$ yards depending upon the season and levels of inundation. The most striking characteristic of Indus River has been its changing courses, contributing immensely in the region's history and shaping of its settlements pattern. Within Sindh there are only two stable portions of the river, one at Sukkur and the other at Kotri (near Hyderabad). Being the only fresh water source in the region, the Indus and its tributaries have been extensively channeled for irrigation purposes providing an 
agricultural base for a large majority of the regions' population. In the light of Sindh's history, it is well established that prior to development of proper road network and railways, Indus, in addition to supporting irrigation, also served as a major highway, continuing to serve the purpose till latter half of $19^{\text {th }}$ century. The British interest in the region in fact, originated with their desire to use the river as an artery of communication both for commercial as well as military purposes.

Sindh's urban population of 14.84 million is unevenly distributed; $71 \%$ concentrating only in three major cities, Karachi, Hyderabad and Sukkur. Even within these three large urban agglomerations the population imbalance is quite stark, with Karachi, the provincial capital, accommodating 9.34 million i.e $62 \%$ of Sindh's urban population (making approximately $25 \%$ of Pakistan's urban and $9 \%$ of its total population - whereas unofficial estimates for Karachi indicate 13 million or $10 \%$ of Pakistan's population): followed by Hyderabad and Sukkur with a population of 1.16 million and 0.3 million respectively. Both in terms of population and area spread, Karachi is more than ten times larger than Hyderabad, the second largest city of the province. Having confronted with a situation of rapid and unprecedented growth of cities combined with constrained financial resources, the region has gradually lost its balance of sustainable growth, as reflected in traditional practices and historic environments.

Sindh's historic cities served as regional centers of learning, hubs of trade and commerce and seats of power and administration. Many of these have declined in their significance as urban centers due to various political, administrative and social changes resulting from Sindh's annexation (1843) by the British forces and later due to the provincially polarized administrative approaches of post-Independence (1947) Pakistan. The process of rapid urbanization and uncontrolled development trends has marred the urban fabric of Sindh's historic cities; continuously undergoing major transformations due to lack of appreciation as valuable historic and cultural national assets; and a resource for achieving economic and environmental sustainability. The campaign for conservation and revival of historic environments thus needs to be aggressively put forward for political support; encouraging policies to ensure survival of these important urban centers, incorporated within the urban development agenda - nationally and provincially.

\section{Transformations of $19^{\text {th }}-20^{\text {th }}$ Century: Beginnings of a shift towards imbalances and disparities}

\subsection{Colonial transformations in Sindh}

Sindh's annexation in 1843 brought with it major transformations: social structure, traditional institutions, landscape, built environment and urban systems, economies, legislative and administrative frameworks ingrained for centuries were put to rather abrupt and often incompatible 'reformations', changing the social and economic character of the society (Khuhro, 1999). Progressive developments in physical infrastructure opened up a new era of advancement and growth, offering new opportunities in commerce and trade. For the British, Sindh remained as a military outpost; thus large cantonments were established throughout the region changing the landscape and scale/ character of Sindh's cities.

The pre-colonial traditional society in Sindh had tribal affiliations; but urban centers were multicultural, having an ethnic and religious mix. Obligatory traditions and customs ensured a balance for peaceful co-existence between different communities and tiers of society. Colonial systems disturbed this balance, creating serious differences and conflicts, resulting in a ruptured society. Major elements of transformation were:

- Extreme empowerment of Hindu traders and moneylenders, resulting in increased indebtedness of local (Muslim) landowners and agriculturists, who started to lose control over their ancestral land (Khuhro, 1999; Cheesman, 1982).

- Redefinition of Sindh's role in the regional and international economic context; from active participation in a wide-ranging system of inter-regional and international trade and commerce, to that of an outlet for the agricultural production of the Punjab (Markovits, 2000).

- Replacing the land tenure and revenue systems, based on resource perceptions and a judicious concern for ecologically-balanced use of land, with colonial systems based on a generalized understanding of agriculture in the Indian Empire, which differed substantially from conditions in Sindh (Chablani, 1951; Postans, 1843; Rahman, 1993).

- Prior to British conquest towns served mainly as administrative headquarters, but additionally had a crafts and industries sector given patronage by the royal families and their associated élites. Local products had international market during $17^{\text {th }}$ and $18^{\text {th }}$ century which underwent a gradual decline following industrial revolution in Europe, and collapsed completely during colonial times with disappearance of local aristocracy. 
- In education sector systems based on religious and social traditions were weakened by a lack of governmental support; and replaced by new systems based on Western ideology.

- British colonization had major impact on the built fabric: traditional environments seen with disdain, were attempted to be sanitized through introduction of municipalities. Colonial developments however, remained divorced from native town areas, creating a dichotomy in the urban fabric, with distinct 'native' and 'European' sections, marked with different sets of planning principles. Smaller towns and villages however, remained uninfluenced, retaining their traditional character.

\subsection{Post-Independence developments}

The creation of independent states of India and Pakistan in August 1947, marks a historical milestone for the region, and more so for Sindh. The resulting mass migrations completely changed the demography; the mass exodus of Hindus and Sikhs, replaced by non-Sindhi Muslims from various parts of sub-continent, created an internal rift on political, cultural and territorial issues.

- Conflict of interests developed between Sindhi Muslims and non-Sindhi Muslim migrants; the former struggling to retain the regions' ethnic and linguistic identity, while the latter fighting to carve a place for themselves as an emergent community and a political power in their newly acquired homeland.

- Sindh's urban centers - Karachi, Hyderabad and Sukkur, became strongholds of Urdu speaking immigrant Mohajirs (controlling 1/3 provincial seats from urban constituencies). However, provincial powers, both politically (dominating over two-thirds of provincial seats) and economically remain controlled by the agrarian élite having large land holdings and unquestioned influence on the Sindhi middle class majority. This results in an unstable provincial government.

- The massive migrant influx starting in 1947, continued well into the 1950s resulting in rapid, unprecedented and uncontrolled growth of cities; collapsing existing municipal systems. Over decades temporary squatter settlements have grown into permanent katchi abadis or informal settlements $(50 \%$ of Karachi's population today lives in katchi abadis suffering from low living standards).

- Post-Independence developments in Sindh, marred by a series of conflicts; both at national (between Sindh and Punjab on Indus water distribution and national revenue share) and provincial (between Mohajirs and Sindhis) level have resulted in extreme disparities. With a magnified urban-rural divide Sindh's urban centers choke with over population, facing serious environmental and ecological issues; whereas rural areas, deprived of sufficient development programs and economic prospects force residents to migrations towards urban centers seeking better employment opportunities.

\section{Sindh's Urban Configuration - Past, Present and Direction for a Sustainable Future}

Urbanization in Sindh is generally associated with the unprecedented expansion of cities following mass migrations during 1947 Partition, but historical background of the region indicates much deeper roots of its urban progress; archaeological discoveries indicating a pattern of settlements much influenced by the movement of the river (Holmes, 1968; Possehl, 1990; Possehl, 1999; Panhwar,1999). Generally the densities remained most dense along the river corridor; within two or more miles from the banks (Thornton, 1844; Flam, 1999). Larger towns of a more permanent nature with a higher population density were located along the river; the main artery of communication. Concentration of these settlements shifted with the changes in the river course. Areas away from the river remained thinly populated; but considerable degree of habitation even in areas distant from the river concentrated around natural water reservoirs or seasonal torrential streams. Settlements in these areas were less permanent with a fluid population, moving around with seasonal changes or availability of resources. Descriptions of Sindh's cities from the $9^{\text {th }}-10^{\text {th }}$ centuries reflect a well developed network of large and small towns, having a nucleus centre - the seat of ruling authority. Smaller towns served as feeders to the larger system. Accounts of later centuries indicate the existence of multi occupational and socially stratified complex urban centers.

A review of the historic timeline of Sindh (table 1) indicates that from the $14^{\text {th }}$ century local Dynasties were established in Sindh, bringing in more stability and prosperity to the region. The concept of a large capital town emerged, with Thatta being the earliest example of it. During these earlier centuries $\left(14^{\text {th }}-17^{\text {th }}\right.$ century) settlements concentrated along the main channel of the river but in addition regional boundaries were guarded by fortified points at the strategic entry points from neighboring lands; examples being Ranikot, Umarkot, Manora (in addition to Bukkur and Sehwan). Up to early $17^{\text {th }}$ century the urbanization process and the rise and decline of cities had dependence on geomorphologic processes in the region, specially hydrology and hydraulics. During $17^{\text {th }}$ century Sindh was annexed to the Mughal Empire, initiating among other developments the irrigation 
schemes, which were further enhanced by the Kalhora and Talpur rulers of $18^{\text {th }}$ and $19^{\text {th }}$ centuries, making cities and settlements more stable in nature; allowing flexibility and larger choice in further developing and expanding the sphere of settled areas. Once the instability of old centers due to the river's changing course was overcome, a complete reshaping of the urban network took place (Markovits, 2008). Towns of Sindh integrated within regional and even interregional urban systems extending much beyond the boundaries of the province (Markovits, 2008). In $18^{\text {th }}$ century Hyderabad superseded Thatta as the capital, which till these times remained the focus or hub of all activities, fed in by a system of smaller supportive towns having specific crafts or agriculture based expertise. Towards end of $18^{\text {th }}$ century, establishment of the Talpur Dynasty brought with it a newer concept of a more decentralized and multi-centered form of administration with three capital towns (Hyderabad, Khairpur, Mirpurkhas) and two main centers of trade and commerce (Karachi and Shikarpoor). The scale of cities, the pattern of their settlements and the administrative systems up till these times, however, remained very similar.

Colonization of Sindh towards mid $19^{\text {th }}$ century introduced a change in administrative pattern as well as vocabulary of built environment and scale of development. Technological advancement in irrigation and communication networks were the major contributions of colonial governance towards urbanization; further encouraging rapid growth of towns. New towns started to emerge as new districts were created and their administrative centers were formed. The urban population at the time of last colonial census in 1941 had reached to some 900,000 out of a total population of 4.5 million (Markovits, 2008). Urban centers however, maintained a close link and dependence on their adjoining rural hinterland, as well as the 'towns and cities of Balochistan, the Punjab and the North-West Frontier Province' (Markovits, 2008). The port of Karachi and the railways network also linked up with extensions beyond the limits of the province; northeast into Punjab, eastwards into Rajasthan, northwest into Balochistan. The growth of cities and their economic prosperity got tied to communication and transportation links; revolutionized during this period.

The urban grid or axis along which urban centers in Sindh developed, is aligned with the River Indus; and has remained unchanged even after the introduction of the railways, which runs parallel to the river. Even the late $20^{\text {th }}$ century developments have retained the urban grid of $18^{\text {th }}$ century, with only a few changes in the communication links; mainly the closure of railway links with Rajasthan across the border and abandonment of caravan trade routes through Bolan Pass in the north western direction after extension of railway towards Quetta. The $20^{\text {th }}$ century's legacy of industrialization and capitalization has also contributed its share to the historic built environment: however, this being concentrated mostly in and around Karachi their impact is of a lesser magnitude elsewhere in the region. The economic prospects particularly created in Karachi have encouraged migrations from other parts of the subcontinent, especially from regions well connected through the railways. This trend is consistently prevalent in consecutive census records, especially since independence (Hasan, 2011).

The urbanization process of pre-partition was planned and well organized, but mass migrations during the first decade after Partition resulted in an unprecedented growth that has ever since accelerated with uncontrolled scale and magnitude. Sindh has been most diversely affected because of its limited natural resources; added with a drastic cut in its revenues due to the major revenue generating establishments based in Karachi, being taken over by the federal government, since Independence, without a fair compensation offered to the province for slicing of its provincial revenue sources. Conflicts in political structure due to demographic changes, and an increasing polarity with the center, have kept the successive governments preoccupied with the power game, rather than addressing the problems of rapid urbanization that are creating an increasing urban crisis that remains unresolved. Lack of initiatives and investments to create economic opportunities to evenly spread throughout the region has resulted in an imbalanced urban growth. The traditional practices of revenue resource management practiced in pre-colonial times, as revealed from historical research on the region, give directions that could be wisely employed for rebalancing the urbanization trends and reviving the natural resources of the region and achieve equilibrium for sustainability. The historic towns in the region, with their inherent values, in combination with the indigenous arts and crafts that still survive in the region are an un-explored resource that can be tapped for putting the region back on an economically stable and sustainable footing.

\section{Sindh's Historic Towns: Identifying the significance and potential values}

Through well established definitions two main factors - size and function are identified as the most important determinants for designating places the status of a town; thus taken as the starting point for identifying the important historic towns of Sindh. The aspect of size is dealt through information from census records and important historic functions identified as significant in the urbanization process of towns listed through a literature review on urban centers combined with Sindh's urban history. This first stage incorporated short-listing of important historic towns from among the list of Sindh's cities having a population of above $>20,000$. The list 
of towns derived through census figures when tabulated against identified historic functions (categorized as pre-colonial and colonial) indicate fifteen surviving urban centers (Thatta, Hyderabad, Sukkur, Karachi, Rohri, Mirpurkhas, Sehwan, Hala, Shikarpoor, Jacobabad, Khairpur, Kotdiji, Umerkot, Jhimpir, Jherruk) as important towns that gained significance due to specific historic functions that were a cause for economic growth and physical expansion, contributing to urban traditions in the region (table 2). The second stage incorporated detailed study of identified ten cases from among the shortlisted towns of historic significance; leading towards an understanding of their typo-morphological form - the analytical outputs indicating four key parameters (function, topography, geographical importance and period contributions) as the main contributing factors shaping the historic built environments in the region.

Sindh cities presently having a population of $>20,000$ when evaluated for their association with important historic functions indicate that urban centres of present times are tied with one common factor, i.e. their link with modern communications network; the railways and highways. But those having $>100,000$ inhabitants, in addition to being well connected, also served either as district headquarters or important British cantonments. Historic towns having a varied range of historic functions grew during colonial period only if given administrative or military importance as district headquarters, capitals or cantonments. Seven identified historic urban centers today have a population of more than 50,000. The remaining eight come within the range of medium and smaller cities of present times; the primary reason for their contained growth or decline seems to be the fact that they were not connected with the railways, which has played an important role in the urbanization and development growth of Sindh and its cities (fig 2 and table 2). Historical profile of at least seven of the identified fifteen historic towns indicates that they served as centers of traditional crafts and industry - each having a specialty of its own. These traditional arts and crafts include glazed terracotta and pottery works, weaving and textiles (sussi, shawls, lunge, khes, carpets, rugs), lacquer work, beaten metal wares, patchwork (rallee, quilts) and block print (ajrak). The negative impacts of industrial revolution resulted in a decline of these traditional crafts, yet they have managed to survive in various forms even till present times. Lack of patronage however, makes it difficult for artisans associated with these crafts to achieve economic viability, thus their younger generations are opting for alternate professions. A possible revival of these crafts, developed as small industries, could be an answer to achieve sustainable economic development in and around the historic towns of the region.

The fifteen identified historic urban centers of Sindh have different combination of functions identifying their significance. The variety of combinations indicates the uniqueness of each. The form and character of built environments in these towns is a result of various factors; primarily the political, economic and religious influences, but in addition their geographic and topographic elements as well, as these have been the basis of human survival in the complex and rather challenging natural environment of Sindh. The most important parameters shaping the built environment in Sindh and impacting on the growth patterns of its cities are (table 3); function, topography, geographic location/ position of the historic town in the wider regional context (impacting the development of communication links) and the period contributions from various political and administrative entities contributing to the development of each city in accordance with its importance and associations (Naeem, 2009). Tabulation of these key parameters (table3) when checked for their influences on each historic town indicates different set of elements/ factors contributing to the development of urban form in each case. This diversity and variety needs to be acknowledged as an enriching asset (both economically and culturally) and incorporated to have a place within the agenda of sustainable development for the province. The specific values identified for each town need to be evaluated in detail, to develop appropriate conservation plans individually for each case that incorporates within it the integrity and authenticity of the historic built environment, the potentials of natural features of the terrain and urban landscape, and the socio-cultural and intangible aspects; with a vision for economic uplift and well-being of associated local communities. The present standards of living need to be enhanced through development investments in the sectors of education, healthcare and recreation. These provisions would help decentralize and distribute the urbanized pockets evenly throughout the region, relieving some of the economic/ commercial pressures from Karachi Hyderabad and Sukkur; the present urban magnets in Sindh.

\section{Conclusions}

Having its diverse range of landscapes and ecosystems Sindh is enriched with natural resources and biodiversity; but their unfortunate over-exploitation today jeopardizes the delicate ecosystems and their associated communities. Among the most striking problems highlighted by IUCN in recent reports on sustainable development and resource management are the issues of desertification, water logging and salinity, and 
extensive intrusion of the sea water into the Indus Delta; leading to social and economic disparity, as well as a high incidence of poverty and rural-urban migrations in the region (IUCN, 2007; IUCN, 2004).

The dynamics and rapidity of changes point towards a number of factors shaping the formation - rise or decline, of cities and urban patterns in Sindh. Among major contributors in earlier times are hydrological changes of the Indus, political influences from outside and within, the dynamics of economic growth and the development of communication links. The influence of these factors and their impact varies in pre-colonial, colonial and post-independence periods. The changes introduced with colonization and latter $20^{\text {th }}$ century developments gradually changed the urban and regional landscape; affecting sustainability of natural and environmental resources of the area. The society has largely remained tied to its cultural values closely linked with an agricultural context, especially in the urban hinterlands. The stress on natural assets of the province and the environment they subsist is more because of their poor management. Although much of the built environment has undergone a change at different times, but there still remain substantial evidences and samples that today enable us to read the multilayered historic traditions of the region. The historic towns of Sindh provide an invaluable resource that gives an insight into regional capacities and potentials built and sustained over centuries. In order to seek a place for the unique built heritage of the region within the present development plans it is of utmost importance that these places are acknowledged and appreciated for their intrinsic values.

Sindh's important historic centers that today continue to survive as cities or towns provide a comprehensive picture of the pattern of urbanization as it evolved over the centuries. An analysis of these historic towns indicates a variety and diversity unique to the region due to a range of physiographic and climatic conditions. An in-depth of these could help develop long term policies that encourage a sustained growth pattern, maintaining continuity of traditional environments. To campaign for this it is essential to acquire political support and develop close collaborations/ co-operation between different government departments, institutions and educational setups.

Recognizing the importance of urban/ historic town conservation as a significant area of professional development; gives a frame of reference to acknowledge the need for linking these with planning policies and development processes visualized at a regional level. It helps reinstate their significance, especially for those towns that no longer hold importance in today's economy and development trends; re-affirming their place on the map as important historic urban centers and national heritage assets requiring a re-integration into the mainstream socio-economic scene within the region. Planning and development policies should thus be oriented towards providing these historic urban centers with substantial development investments to boost their socio-economic and cultural activities.

\section{References}

Airs, M. (2006). Protecting the Historic Environment: The Legacy of W. G. Hoskins. Journal of Architectural Conservation. 12 (3), 19-33.

Breheny, M. (1992). Sustainable Development and Urban Form. London: Pion.

Brimblecombe, P., Grossi, C. (2006). Scientific Research into Architectural Conservation. Journal of Architectural Conservation. 12 (3), 127-135.

Carter, H. (1983). An Introduction to Urban Historical Geography. London: Edward Arnold.

Chablani, S. P. (1951). Economic Condition in Sind - 1592 to 1843. Bombay: Orient Longmans Ltd.

Cheesman, D. (1982). The Omnipresent Bania: Rural Moneylenders in Nineteenth - Century Sind. Modern Asian Studies. 16 (3), 445-462.

Elkin, T., McLaren, D., Hillman, M. (1991). Reviving the City: Towards Sustainable Urban Development. London: Friends of the Earth.

Flam, L. (1999). Ecology and Population Mobility in the Prehistoric Settlement of the Lower Indus Valley, Sindh, Pakistan. In Meadows, A., Meadows, P. (Eds.) The Indus River: Biodiversity Resources Humankind. Karachi: Oxford University Press.

Garnier, B., Chabot, G. (1967). Urban Geography: Geographies for Advanced Studies. London: Longmans.

Population Census Organization, Government of Pakistan (2009) Population by Province/ Region since 1951. [Online] Available: http://www.statpak.gov.pk/depts/pco/statistics/pop_by_province/pop_by_province.html (May 10, 2009)..

Hasan, A., Raza, M. (2011). Migrations and Small Towns in Pakistan. Karachi: Oxford University Press. 
Heath, T. (2000). Achieving Sustainable Urban Form through the Adaptive Reuse of Buildings for Residential Use. In Williams, K., Jenks, M. \& Burton, E. (Eds.) Achieving Sustainable Urban Form. London: E. \& F. N. Spon.

Holmes, D. A. (1968). The Recent History of the Indus. The Geographical Journal. 134 (3), 367-382.

IUCN (2004). Sindh State of Environment and Development. Karachi: IUCN Pakistan - Sindh Program.

IUCN (2007). Sindh Strategy for Sustainable Development. Karachi: IUCN Pakistan - Sindh Program.

Khuhro, H. (1999). The Making of Modern Sindh - British Policy and Social Change in the 19th Century. Karachi: Oxford University Press.

Knox, P., Mayer, H. (2009). Small Town Sustainability: Economic, Social, and Environmental Innovation. Berlin: Birkhäuser.

Markovits, C. (2000). The Global World of Indian Merchants, 1750-1947: Traders of Sind from Bukhara to Panama. Cambridge: Cambridge University Press.

Markovits, C. (2008). Urban Society in Colonial Sindh (1843 - 1947). In Boivin, M. (Ed.). Sindh Through History and Representations: French Contributions to Sindhi Studies. Karachi: Oxford University Press.

Naeem, A. (2009). Recognizing Historic Significance Using Inventories: A Case of Historic Towns in Sindh, Pakistan. Oxford: PhD thesis - Oxford Brookes University.

Pickard, R. D. (2001). Management of Historic Centres. London: Spon Press.

Pickard, R. (2002). Area Based Protection Mechanisms for Heritage Conservation: A European Comparison. Journal of Architectural Conservation. 8 (2), 69-88.

Panhwar, M. H. (1999). Seepage of Water of the River Indus and Occurrence of Fresh Ground Water in Sindh. In Meadows, A., Meadows, P. (Eds.). The Indus River: Biodiversity Resources Humankind. Karachi: Oxford University Press.

Possehl, G. L. (1990). Revolution in Urban Revolution: The Emergence of Indus Urbanisation. Annual Review of Anthropolgy. 19, 261-282.

Possehl, G. L. (1999). Prehistoric Population and Settlement in Sindh. In Meadows, A., Meadows, P. (Eds.). The Indus River: Biodiversity Resources Humankind. Karachi: Oxford University Press.

Postans, T. (1843). Personal Observations on Sindh. London: Longman, Brown, Green and Longmans.

Rahman, M. (1993). Land and Life in Sindh, Pakistan. Lahore: Ferozsons (Pvt.) Ltd.

Rodwell, D. (2003). Sustainability and the Holistic Approach to the Conservation of Historic Cities. Journal of Architectural Conservation. 9 (1), 58-73.

Sorley, D. H. T. (1959). Gazetteer of West Pakistan: The Former Province of Sindh Khairpur State. Authority of Government of West Pakistan.

Thornton, E. (1844). A Gazetteer of Countries Adjacent to India on the North-West Including Sinde, Afghanistan Beloochistan, the Punjab and the Neighboring States.

Wallace, J., Higgins, M., Raemaekers, J. (1999) Architectural Conservation and Environmental Sustainability: Conflict or Convergence?. Journal of Architectural Conservation. 5 (2), 56-71.

World Commission on Environmental and Development (1987). The Brundtland Report, Our Common Future. Oxford: Oxford University Press.

Williams, K., Burton, E., Jenks, M. (2000). Achieving SustainableUrban Form. London: E. \& F. N. Spon. 
Table 1. Historic timeline of Sindh indicating period contributions to the built fabric. Towns marked with a dot now exist only as archaeological sites

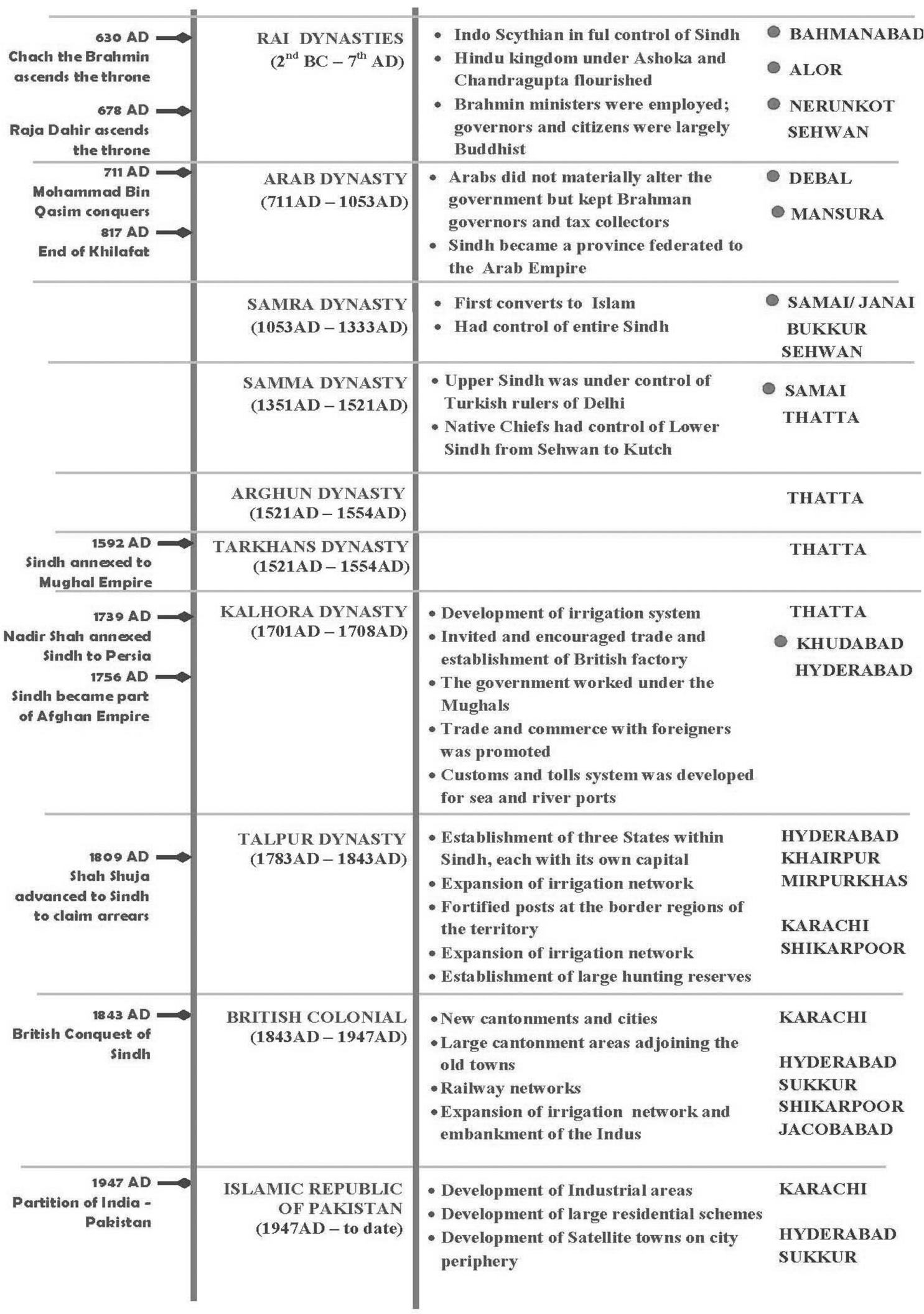


Table 2. Evaluation for determining significance in terms of contributing historic functions of cities in Sindh (all towns having population of $>20,000$ inhabitants are taken into consideration)

\begin{tabular}{|c|c|c|c|c|c|c|c|c|c|c|c|c|}
\hline & \multicolumn{10}{|c|}{ HISTORIC CITIES OF SINDH } \\
\hline & & & 苞 & 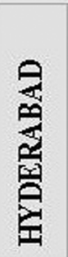 & 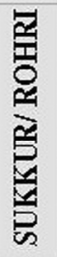 & \multirow[t]{2}{*}{ 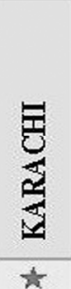 } & \multirow[t]{2}{*}{ 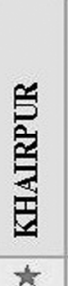 } & \multirow[t]{2}{*}{ 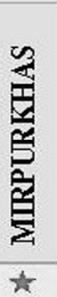 } & \multirow[t]{2}{*}{ 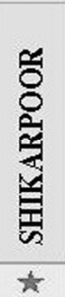 } & \multirow[t]{2}{*}{ 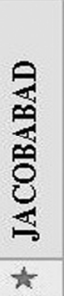 } & \multirow{2}{*}{ 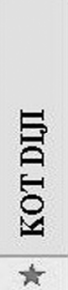 } & $\begin{array}{l}5 \\
\vdots \\
\vdots \\
3 \\
3\end{array}$ \\
\hline \multirow{6}{*}{\multicolumn{2}{|c|}{ FUNCTIONS }} & Trade/ Transit Node & $\star$ & $\star$ & म & & & & & & & \# \\
\hline & & Defense/ Military & $\not$ & $\star$ & $\star$ & $\star$ & & 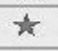 & $\star$ & $\star$ & $\star$ & $\star$ \\
\hline & & Administrative center & $\star$ & $\star$ & $\star$ & $\star$ & $\star$ & $\star$ & $\star$ & $\star$ & & $\star$ \\
\hline & & Religious Center & & & $\star$ & & & & & & & \\
\hline & & $\begin{array}{l}\text { Center of crafts/ } \\
\text { industry }\end{array}$ & $\star$ & $\not$ & $\star$ & & $\star$ & $\star$ & & & & \\
\hline & & $\begin{array}{l}\text { Archaeological } \\
\text { Significance }\end{array}$ & 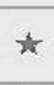 & $\star$ & $\star$ & $\star$ & & $\star$ & & & $\star$ & \\
\hline \multirow{4}{*}{\multicolumn{2}{|c|}{ TOPOGRAPHY }} & Hilly & $\star$ & $\star$ & $\star$ & & & & & & $\star$ & \\
\hline & & Alluvial Plains & $\star$ & $\star$ & & & $\star$ & & $\star$ & $\star$ & & \\
\hline & & $\begin{array}{l}\text { Arid Plains fed by } \\
\text { canals }\end{array}$ & & & & & & $\star$ & & & & 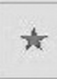 \\
\hline & & Delta Plains & & & & $\star$ & & & & & & \\
\hline \multirow{7}{*}{ 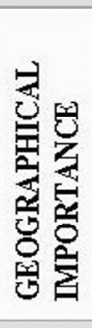 } & \multirow[t]{3}{*}{ Railway } & Passes on Periphery & & & & & $\star$ & & $\star$ & $\star$ & & \\
\hline & & Cuts through & & $\hbar$ & $\star$ & $\star$ & & $\hbar$ & & & & \\
\hline & & Does not link & $\star$ & & & & & & & & $\star$ & $\star$ \\
\hline & \multirow[t]{2}{*}{ Highway } & Passes on periphery & $\star$ & $\star$ & 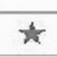 & & $\star$ & & $\star$ & & $\star$ & \\
\hline & & Cuts Through & & & & $\star$ & & $\star$ & & $\star$ & & $\star$ \\
\hline & \multirow{2}{*}{$\begin{array}{l}\text { Regional } \\
\text { Roads } \\
\text { Pattern }\end{array}$} & Linear & $\star$ & $\star$ & $\star$ & $\star$ & $\star$ & & & $\star$ & $\star$ & \\
\hline & & Radial/ Nodal & & & & & & 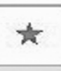 & $\star$ & & & $\star$ \\
\hline \multirow{16}{*}{ 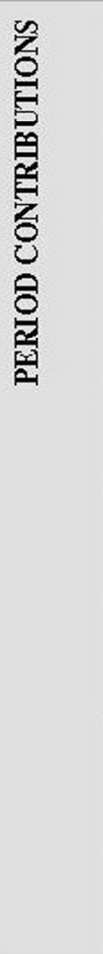 } & \multirow{7}{*}{ 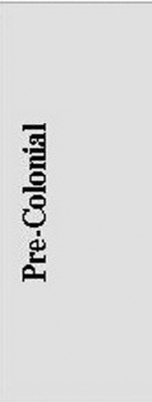 } & Fort/ Fortifications & $\star$ & $\star$ & $\star$ & $\star$ & & $\star$ & $\star$ & $\star$ & $\star$ & $\star$ \\
\hline & & Shahi Bazaar & $\star$ & $\star$ & $\star \star$ & & & & $\star$ & & & \\
\hline & & $\begin{array}{l}\text { Narrow/ winding } \\
\text { street pattern }\end{array}$ & म & $\star$ & $\star$ & $\star$ & $\star$ & $\star$ & $\downarrow$ & & 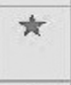 & 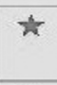 \\
\hline & & Irrigation canals & $\star$ & $\star$ & $\star$ & & $\star$ & $\star$ & $\star$ & $\star$ & $\star$ & $\star$ \\
\hline & & Public Monuments & $\star$ & $\star$ & $\star$ & & $\star$ & & $\star$ & $\star$ & & \\
\hline & & Private Monuments & & $\star$ & & & t & & $\not$ & & $\star$ & \\
\hline & & $\begin{array}{l}\text { Commemorative/ } \\
\text { funerary Monuments }\end{array}$ & $\star$ & $\star$ & $\star$ & $\star$ & $\star$ & $\star$ & $\star$ & & & \\
\hline & \multirow{5}{*}{ 졀 } & $\begin{array}{l}\text { Cantonment/ } \\
\text { European Quarters }\end{array}$ & & $\star$ & $\star$ & $\star$ & & & $\star$ & $\star$ & & \\
\hline & & Civil Quarters & & $\star$ & $\star$ & $\star$ & & & $\star$ & $\star$ & & \\
\hline & & Railways colony & & & $\star$ & $\star \star$ & & & म & & & \\
\hline & & $\begin{array}{l}\text { Irrigation canals/ } \\
\text { colony }\end{array}$ & म & t & $\star$ & & 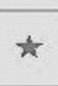 & & & & & \\
\hline & & $\begin{array}{l}\text { Public buildings/ } \\
\text { monuments }\end{array}$ & & $\star$ & $\star$ & $\star$ & $\star$ & $\star$ & $\star$ & $\star$ & & \\
\hline & \multirow{4}{*}{ 总 } & Refugee Settlements & & 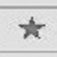 & $\star$ & ฟ & 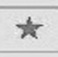 & & & & & \\
\hline & & $\begin{array}{l}\text { Satellite towns/ } \\
\text { residential colonies }\end{array}$ & $\star$ & $\star$ & $\star$ & $\star$ & $\star$ & & & & & \\
\hline & & $\begin{array}{l}\text { Industrial } \\
\text { establishments }\end{array}$ & & $\star$ & $\star$ & $\star$ & $\star$ & $\star$ & & & & \\
\hline & & Modern landmarks & & & & $\star$ & & & & & & \\
\hline
\end{tabular}


Table 3. The four key factors identified as important contributing aspects towards shaping of historic environments in Sindh

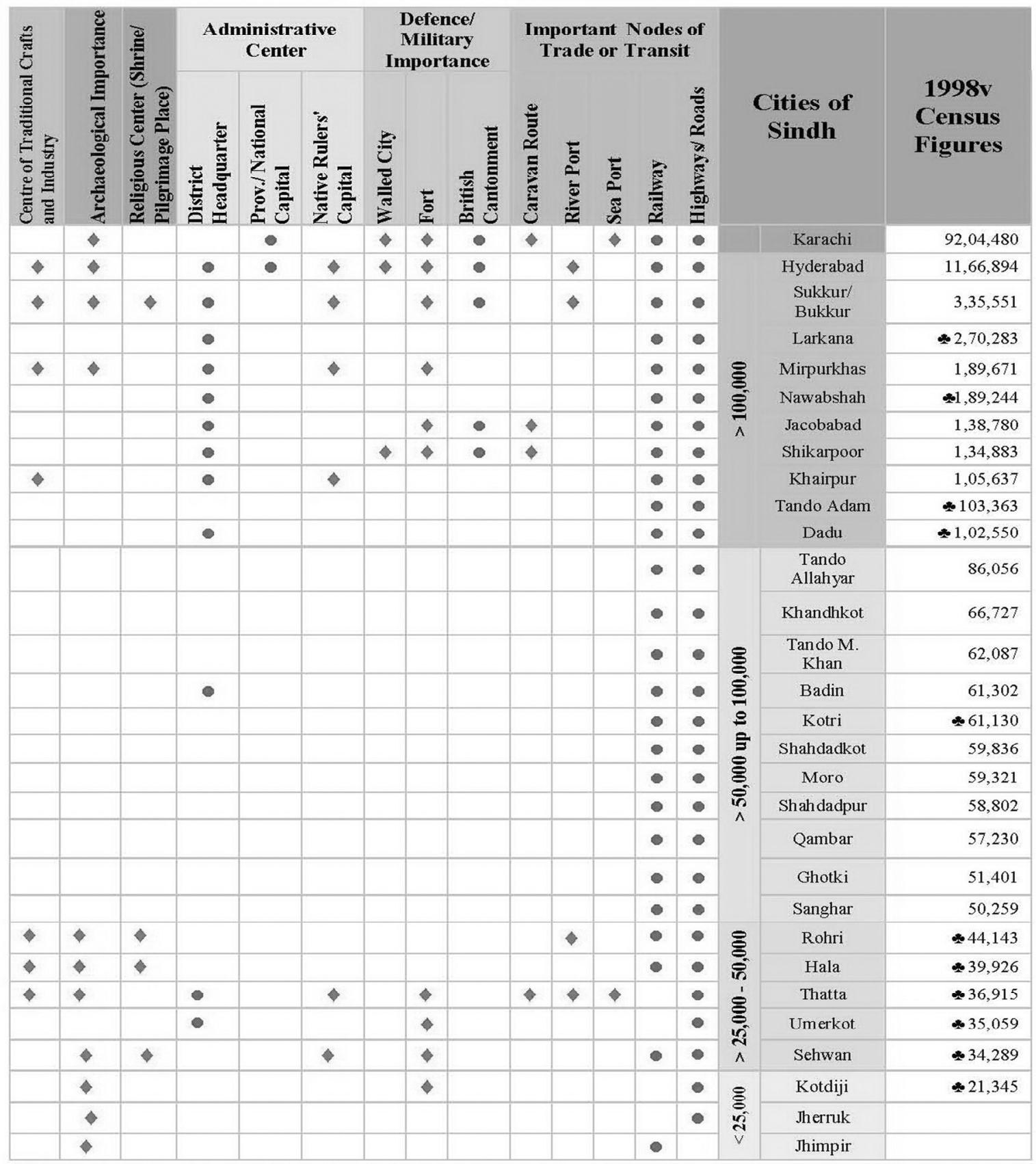

( $\downarrow$ ) corresponds to historic significance pre-dating colonial period. Most of these functions gave significance to any town as an important urban centre in historic times, but started to become redundant during the colonial period (with the exception of sea port) and gradually lost their value due to developmental initiatives taken for the region during and after colonial times.

(•) corresponds to functions that raised significance of a town during colonial period, which more or less are also valid for present times except for the British Cantonments. 


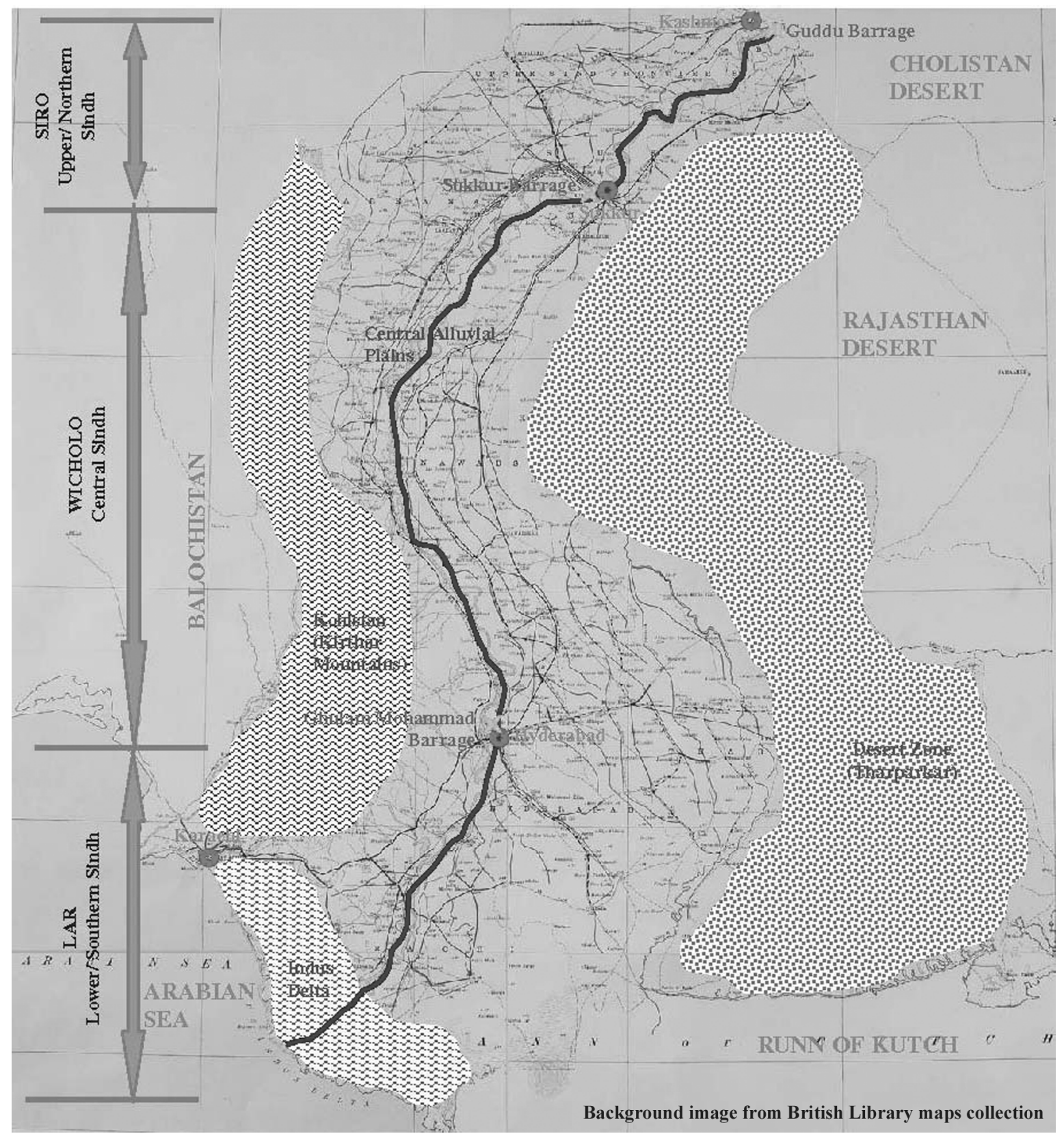

Figure 1. Topographic Sub-divisions of Sindh 


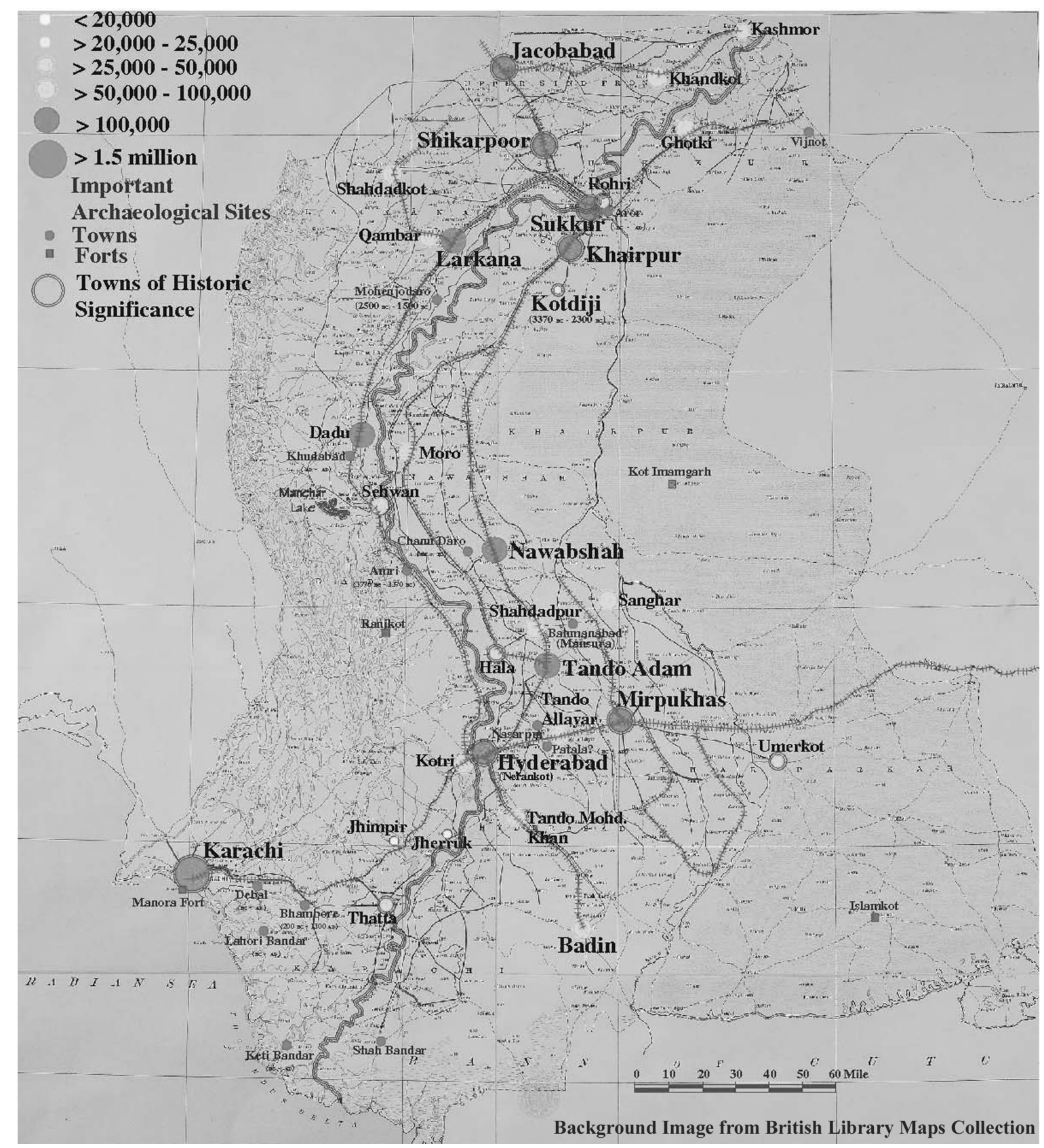

Figure 2. Map of Sindh showing present urban centers/ historic towns, along with important archaeological sites. Relationship of settlements with railways and present course of river is also clearly seen 